\title{
ETHICS IN RESEARCH WITH HUMAN SUBJECTS - A BRIEF REVIEW
}

MD. UZIRE AZAM KHAN ${ }^{1}$, MD. RUHUL AMIN², FIROZA BEGUM ${ }^{3}$, MOMOTAZ BEGUM ${ }^{4}$

${ }^{1}$ Lecturer ${ }^{2}$ Professor, ${ }^{3}$ Associate professor, ${ }^{4}$ Assistant professor, Department of Physiology, Dhaka Medical Colllege, Dhaka.

\begin{abstract}
Ethics in research involving humans were first codified in 1946 as Nuremberg code. Subsequently other ethical declarations and guide lines were developed to protect the research participants as well as the researchers. The basic research bioethics includes three principles-respects for person, beneficence, and justice. To make a research with human subjects ethically sound the research protocol should have social and scientific values, fair subject selection, favorable risk benefit ratio, independent review, and informed consent of and respect for the participants. Above all the researcher should be honest and responsible enough to safeguard the rights and welfare of the research subjects.
\end{abstract}

(Bangladesh J Physiol Pharmacol 2009; 25(1\&2) : 24-26)

\section{INTRODUCTION}

Research is done for the wellbeing of human being. So research on man for the interest of science and society should never take precedence over the considerations related to the wellbeing of the subjects.

Historical aspect: Concerns about the ethics of the practice of medicine have a long history but, until the middle of this century, they were mostly centered round the practice of therapeutic medicine, not research medicine. In 1946, 23 Nazi physicians went on trial at
Nuremberg for crimes committed against prisoners of war. These crimes included exposure of humans to extremes of temperature, performance of mutilating surgery, and deliberate infection with a variety of lethal pathogens. During the trial, fundamental ethical standards for the conduct of research involving humans were codified into the Nuremberg Code, which set forth ten conditions that must be met to justify research involving human subjects. The two most important conditions were the need for voluntary informed consent of subjects and a scientifically-valid research design that could produce fruitful results for the good of the society ${ }^{1}$.

Table -I

Ethical Declarations and guidelines: Historical Perspective. ${ }^{2}$

\begin{tabular}{|c|c|c|}
\hline Guidelines & Sources & Year and revision \\
\hline Nuremberg Code ${ }^{3}$ & Nuremberg Military Tribunal Decision & 1947 \\
\hline Declarations of Helsinki ${ }^{4}$ & World Medical Association & $\begin{array}{l}1964,1975,1983 \\
1989,1996,2000\end{array}$ \\
\hline $\begin{array}{l}\text { Belmont Report } 5 \\
\text { and Behavioral Research }\end{array}$ & $\begin{array}{l}\text { National Commission for the Protection } \\
\text { of Human Subjects of Biomedical }\end{array}$ & 1979 \\
\hline $\begin{array}{l}\text { International Ethical Guideline for } \\
\text { Research Involving Human Subjects }\end{array}$ & $\begin{array}{l}\text { Council for International Organizations } \\
\text { of Medical biomedical Sciences (CIOMS) }\end{array}$ & $\begin{array}{l}\text { Proposed in } \\
1982 \text { Revised } \\
\text { in 1993, } 2002\end{array}$ \\
\hline $\begin{array}{l}\text { Guidelines for Good Clinical Practice } \\
\text { for Trial on Pharmaceutical Products }\end{array}$ & World Health Organization & 1995 \\
\hline $\begin{array}{l}\text { Operational Guidelines for Ethics Committees } \\
\text { That Review Biomedical Research }\end{array}$ & World Health Organization & 2000 \\
\hline $\begin{array}{l}\text { The Ethics of Research Related to } \\
\text { Health Care in Developing Countries }\end{array}$ & Nuffield Council on Bioethics & 2001 \\
\hline Survey and Evaluating Ethical Review Practice & World Health Organization & 2002 \\
\hline
\end{tabular}

Address of Correspondence: Dr. Md. Uzire Azam Khan, Lecturer, Department of Physiology, Dhaka Medical Colllege, Dhaka. 


\begin{tabular}{|c|c|c|c|}
\hline Requirement & Explanation & $\begin{array}{l}\text { Justifying ethical } \\
\text { values }\end{array}$ & $\begin{array}{l}\text { Expertise } \\
\text { evaluation }\end{array}$ \\
\hline $\begin{array}{l}\text { Social or } \\
\text { scientific } \\
\text { value }\end{array}$ & $\begin{array}{l}\text { Evaluation of a treatment, intervention, or } \\
\text { theory that will improve health and well- } \\
\text { being or increase knowledge }\end{array}$ & $\begin{array}{l}\text { Scare resources } \\
\text { and non- } \\
\text { exploitation }\end{array}$ & $\begin{array}{l}\text { Scientific knowledge, } \\
\text { citigens' understanding of } \\
\text { social priorities }\end{array}$ \\
\hline $\begin{array}{l}\text { Scientific } \\
\text { validity }\end{array}$ & $\begin{array}{l}\text { Use of accepted scientific principles and } \\
\text { methods, including statistical techniques, to } \\
\text { produce reliable and valid data }\end{array}$ & $\begin{array}{l}\text { Scare resources } \\
\text { and non- } \\
\text { exploitation }\end{array}$ & $\begin{array}{l}\text { Scientific and statistical } \\
\text { knowledge, knowledge of } \\
\text { conditionand population to } \\
\text { assess feasibility }\end{array}$ \\
\hline $\begin{array}{l}\text { Fair subject } \\
\text { selection }\end{array}$ & $\begin{array}{l}\text { Selection of subjects so that stigmatized and } \\
\text { vulnerable individuals are not targetedfor } \\
\text { risky research and the rich and socially } \\
\text { powerful not favored for potentially beneficial } \\
\text { research }\end{array}$ & Justice & $\begin{array}{l}\text { Scientific knowledge; } \\
\text { ethical and legal } \\
\text { knowledge }\end{array}$ \\
\hline $\begin{array}{l}\text { Favorable } \\
\text { risk- benefit } \\
\text { ratio }\end{array}$ & $\begin{array}{l}\text { Minimization of risk; enhancement of } \\
\text { potential benefit; risk to the subject are } \\
\text { proportionate to the benefits to the subject } \\
\text { and society }\end{array}$ & $\begin{array}{l}\text { Nonmaleficence, } \\
\text { beneficence and } \\
\text { Nonexploitation }\end{array}$ & $\begin{array}{l}\text { Scientific knowledge, } \\
\text { citizen's understanding of } \\
\text { social values. }\end{array}$ \\
\hline $\begin{array}{l}\text { Independent } \\
\text { review }\end{array}$ & $\begin{array}{l}\text { Review of the design of the research trial, its } \\
\text { proposed subject population and risk- } \\
\text { benefit ratio by individuals unaffiliated with } \\
\text { the research }\end{array}$ & $\begin{array}{l}\text { Public } \\
\text { accountability; } \\
\text { Minimizing } \\
\text { influences of } \\
\text { potential conflicts } \\
\text { of interest }\end{array}$ & $\begin{array}{l}\text { Intellectual, financial and } \\
\text { Otherwise independent } \\
\text { researchers; scientific } \\
\text { and ethical knowledge }\end{array}$ \\
\hline $\begin{array}{l}\text { Informed } \\
\text { consent }\end{array}$ & $\begin{array}{l}\text { Provision of information to subjects about } \\
\text { purpose of the research, its procedures } \\
\text { potential risks, benefits and alternatives, so } \\
\text { that the individual understands this } \\
\text { information and can make a voluntary } \\
\text { decision whether to enroll and continue to } \\
\text { participate }\end{array}$ & $\begin{array}{l}\text { Respect for } \\
\text { subject } \\
\text { autonomy }\end{array}$ & $\begin{array}{l}\text { Scientific knowledge; } \\
\text { ethical and legal } \\
\text { knowledge }\end{array}$ \\
\hline $\begin{array}{l}\text { Respect for } \\
\text { potential and } \\
\text { enrolled } \\
\text { Subjects }\end{array}$ & $\begin{array}{l}\text { Respect for subjects by } \\
>\text { permitting withdrawal from the } \\
\text { research } \\
>\text { protecting privacy through confidentiality } \\
>\text { informing subjects of newly discovered } \\
\text { risks or benefits } \\
>\text { informing subjects of results of clinical } \\
\text { research } \\
>\text { maintaining welfare of subjects }\end{array}$ & $\begin{array}{l}\text { Respect for } \\
\text { subject } \\
\text { Autonomy and } \\
\text { welfare }\end{array}$ & $\begin{array}{l}\text { Scientific knowledge; } \\
\text { ethical and legal } \\
\text { knowledge; knowledge of } \\
\text { particular subject } \\
\text { population }\end{array}$ \\
\hline
\end{tabular}

\section{Basics of bioethics. ${ }^{5}$}

The Belmont Report-Ethical Principles and Guidelines for the Protection of Human Subjects, which was published in 1979, provides the philosophical underpinnings for the current laws governing human subjects research. Although other important principles sometimes apply to research, three basic principles provide a comprehensive framework for ethical decision- making in research involving human subjects, these are: Respect for persons, beneficence, and justice.

1. The principle of Respect for Persons acknowledges the dignity and autonomy of individuals, and requires that people with diminished autonomy be provided special protection. This principle requires that subjects give informed consent to participation in research. Because of their potential vulnerability, 
certain subject populations are provided with additional protections. These include live human fetuses, children, prisoners, the mentally disabled, and people with severe illness.

2. The principle of beneficence requires to protect individuals by maximizing anticipated benefits and minimizing possible harms. Therefore, it is necessary to examine carefully the design of the study and its risks and benefits including, in some cases, identifying alternative ways of obtaining the benefits sought from the research. Research risks must always be justified by the expected benefits of research.

3. The principle of Justice requires that we treat subjects fairly. For example, subjects should be carefully and equitably chosen to insure that certain individuals or classes of individuals - such as prisoners, elderly people, or financially impoverished people - are not systematically selected or excluded, unless there are scientifically or ethically valid reasons for doing so. Also, unless there is careful justification for an exception, research should not involve persons from groups that are unlikely to benefit from subsequent applications of the research.

\section{ELEMENTS OF A RESEARCH PROTOCOL ${ }^{1}$}

Investigators conducting or collaborating research involving human subjects must receive approval by an Institutional Review Board (IRB) before they begin their study. Generally, an investigator provides the IRB with a research protocol, which is a written description of, and scientific rationale for, the proposed research activity. It includes a discussion of the human subject protection issues that are relevant to the study and addresses, at a minimum: the risks to subjects; all procedures which are experimental; the anticipated benefits to subjects, if any; the anticipated number of subjects; the proposed consent document and consent process to be used, and appropriate additional safeguards if potentially vulnerable subjects are to be enrolled. Potentially vulnerable subjects may include the elderly, prisoners, children, cognitively impaired individuals, or people who are economically or educationally disadvantaged.

The seven requirements make research with human being ethical ${ }^{7}$. They are

1. Social or scientific value

2. Scientific validity

3. Fair subject selection

4. Favorable risk-benefit ratio

5. Independent review

6. Informed consent

7. Respect for potential and enrolled subjects

\section{CONCLUSION}

Research investigator should be honest and responsible enough to safeguard the rights and welfare of the people participating in their research activities. On the other hand, society should have a law to protect human research subject and researcher as well and to promote ethically sound research.

\section{REFERENCES}

1. Guidelines for the conduct of Research involving human

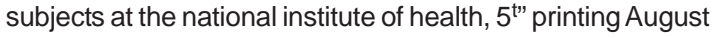
2004. US Department of health and human services.

2. Lecture notes of Professor Harun-Ar-Rashid, Director, Bangladesh Medical Research Council, Bangladesh.

3. Regulation and Ethical Guidelines Nuremberg code

4. World Medical association Declaration of Helsinki.Ethical Principles for Medical Research involving human subjects: basic aspects.

5. Regulation and Ethical Guidelines Belmont Report

6. Council for International Organizations of Medical Sciences (CIOMS) cited in Lecture notes of Professor Harun-ArRashid, Director, Bangladesh Medical Research Council, Bangladesh.

7. Emanual EJ et al. What makes clinical research ethical? JAMA, May, 2000;283(20):2701-2711. 